\title{
Questes
}

\section{« Mors de fain » ou « Fain d'amor »: désirs alimentaires et désirs amoureux dans les fabliaux}

\section{Caroline Foscallo}

\section{(2) OpenEdition}

1 Journals

\section{Édition électronique}

URL : http://journals.openedition.org/questes/2717

DOI : 10.4000/questes. 2717

ISSN : 2109-9472

\section{Éditeur}

Les Amis de Questes

\section{Édition imprimée}

Date de publication : 15 juin 2007

Pagination : $35-48$

ISSN : 2102-7188

\section{Référence électronique}

Caroline Foscallo, « «Mors de fain » ou «Fain d'amor » : désirs alimentaires et désirs amoureux dans les fabliaux », Questes [En ligne], 12 | 2007, mis en ligne le 15 janvier 2014, consulté le 20 avril 2019. URL : http://journals.openedition.org/questes/2717 ; DOI : 10.4000/questes.2717

Ce document a été généré automatiquement le 20 avril 2019.

(c) Association des amis de «Questes » 
« Mors de fain » ou « Fain d'amor»

: désirs alimentaires et désirs

amoureux dans les fabliaux

\author{
Caroline Foscallo
}

NOTE DE L'ÉDITEUR

Cet article n'a pas encore fait l'objet d'une autorisation de publication.

INDEX

Keywords : hunger, fabliau, food, sin, gluttony, sexuality Mots-clés : faim, fabliau, péché, gourmandise, sexualité 